\title{
IRAK2 Gene
}

National Cancer Institute

\section{Source}

National Cancer Institute. IRAK2 Gene. NCI Thesaurus. Code C26301.

This gene is involved in the immune response and signal transduction. 